\title{
PROSVJETITELJSTVO I PREDODŽBE O STANOVNIŠTVU VOJNE KRAJINE U 18. STOLJEĆU
}

\section{Sanja Lazanin}

UDK: 930:316.647.8

Sažetak: U radu se polazi od pretpostavke da se promjene i reforme, koje se tijekom 18. stoljeća provode na brojnim područjima života unutar Habsburške Monarhije, mogu pratiti i kroz njihov utjecaj na percepciju i stvaranje slike o Drugome. Kao polazište za analizu poslužili su narativni izvori dvojice habsburških časnika, grofa Rabatte i vojvode SachsenHildburghausena, koji sadrže opise krajiškog društva. Usporedbom opisa dvojice časnika autorica je analizirala predodžbe i stavove o stanovništvu na području Vojne krajine u Hrvatskoj početkom i krajem 18. stoljeća i nastojala utvrditi na temelju kojih se elemenata oni oblikuju. Pozornost se usmjerila i na određene pojmove karakteristične za razdoblje prosvjetiteljstva koje su oba habsburška časnika upotrebljavala u svojim spisima. U radu se zaključuje da se prikazi tradicionalnih vojnokrajiških zajednica u Rabattinim i Hildburghausenovim opisima javljaju segmentirano i da odražavaju interese i očekivanja koje je monarhijska politika imala od vojnokrajiškog društva.

Ključne riječi: prosvjetiteljstvo, predodžbe i slike o Drugome, krajiško stanovništvo, Vojna krajina

\section{Uvod}

$\int$ ve brojnija istraživanja unutar društvenih i humanističkih znanosti bave se problemima stereotipa i predrasuda, slikom Drugoga, autopredodžbama i heteropredodžbama primjenjujući imagološki pristup na različite društvene, kulturne, povijesne i druge fenomene.

Predodžbe i stavovi o drugima javljaju se u svim povijesnim razdobljima bez obzira na koji su se način izražavali. Upravo je 18. stoljeće razdoblje u kojemu se zbog kulturnog, društvenog, znanstvenog i tehničkog razvitka umnažaju pisani tragovi takve vrste, a mogu se pratiti kroz sve brojniju putopisnu, etnografsku i prirodopisnu literaturu. ${ }^{1} \mathrm{Uz}$ analizu stavova i mišljenja o drugima sadržanih u takvoj vrsti spisa otvara se mogućnost za različite

$1 \quad$ Iz brojne literature o stereotipima izdvojit ću nekoliko radova iz njemačkog govornog područja koji se bave konstrukcijom etničkih stereotipa i stvaranjem slika o Drugome tijekom 18. stoljeća. Radovi se temelje na putopisnoj literaturi 
analize, od toga, što je predmet stereotipnog mišljenja, preko vrste predodžbi i stereotipa pa sve do njihovih značenjskih i sadržajnih promjena i načina izražavanja. Iz povjesničarske perspektive relevantnim se čini pitanje: koliko su pojedine predodžbe o drugima i stavovi prema njima postojani i u kojoj mjeri oni ovise o osobama koje ih izražavaju i prenose, a koliko ovise o određenom povijesnom kontekstu i okolnostima?

U radu se polazi od pretpostavke da se utjecaji promjena i reformi, koje su se provodile tijekom 18. stoljeća u Habsburškoj Monarhiji, mogu uočiti i analizirati kroz percepciju Drugoga i stvaranje slike o Drugome.

\section{Izvori i pristup}

Analiza se temelji na nekoliko Rabattinih i Hildburghausenovih spisa koji sadrže tvrdnje i opise na temelju kojih je moguće napraviti usporedbu razlika i sličnosti njihove percepcije i stavova o stanovništvu u hrvatskom dijelu Vojne krajine. To su Hildburghausenov Beitrag zur Geschichte der Warasdiner und Karlstaedter Grenz Verfassung mit 112 Beylagen (Prilog povijesti ustroja Varaždinske i Karlovačke krajine sa 112 priloga) iz $1781 .^{2}$ i dva Rabattina izvještaja o stanju Karlovačkoga generalata iz 1709. i $1719 .^{3}$

Prilikom primjene imagološkog pristupa u historiografskom tekstu moraju se uzeti u obzir određena ograničenja. Kao prvo, u historiografskoj se analizi, uglavnom, ne polazi od književnoga teksta kao primarnog izvora imagoloških istraživanja u kojemu se opisuju osobine nekoga naroda ili skupine, već se ona temelji na povijesnim izvorima proizišlim iz poslovnih potreba - u ovom radu riječ je o službenim spisima vojnih časnika. Za razliku od književnih tekstova u kojima se prikazuju karakteri pojedinih naroda, slike i predodžbe iz analiziranih povijesnih izvora nisu nastale $s$ namjerom da govore o nacionalnom karakteru stanovnika hrvatske Vojne krajine, već je karakterizacija stanovništva poslužila autorima izvora za opravdanje vlastitih postupaka. Iako su se predodžbe o drugim narodima učinkovito širile i veoma često, upravo putem književnih djela, postajale stereotipi, određeni doprinos njihovu nastanku valja pripisati političkim i drugim aktivnostima zabilježenima u različitim pisanim izvorima. Predodžbe o drugim narodima mogu se shvatiti kao opća mjesta koja u dugom razdoblju preko književnih tekstova utječu na nacionalnu karakterizaciju. Tako stvoreni karakteri nisu rezultat empirijskog opažanja već određenih općih

odnosno etnografskim opisima, a pristupom i predmetom istraživanja poslužili su kao polazište za ovaj rad, usp. Wolfgang HÖPKEN, "Ethnische Stereotype in Südosteuropa", Das Bild des Anderen in Siebenbürgen. Stereotype in einer multiethnischen Region, (ur. Konrad Gündisch, Wolfgang Höpken i Michael Markel), Köln-Weimar-Wien 1998, 7-31; Maximilian GROTHAUS, "Zum Türkenbild in der Adels- und Volkskultur der Habsburgermonarchie von 1650 bis 1800", Wiener Beiträge zur Geschichte der Neuzeit. Das Osmanische Reich und Europa 1683 bis 1789: Konfikt, Entspannung und Austausch, sv. 10, Wien 1983, 63-88; Helga FISCHER, "Das Osmanische Reich in Reisebeschreibungen und Berichten des 18. Jahrhunderts", Wiener Beiträge zur Geschichte der Neuzeit. Das Osmanische Reich und Europa 1683 bis 1789: Konflikt, Entspannung und Austausch, sv. 10, Wien 1983, 113-142; Franz K. STANZEL (ur.), Europäischer Völkerspiegel. Imagologisch-ethnologische Studien zu den Völkertafeln des frühen 18. Jahrhunderts. Heidelberg 1999.

2 Kriegsarchiv, Beč (dalje: KA), Hofkriegsrat-Kanzleiarchiv (dalje: HKR-KZLA) VII 349, fasc. 1, fol. 1-47.

3 KA, HKR, 1710 VI 219, Expedit, fol. 1-74, Relation des Standes der Carlstätterischen vnd Meer Gränitzen, 1709; KA, HKR, 1721 I 457, Expedit, fol. 1-43, Gehorsamste und dienstschuldige Relation über die mir anbefohlene Gräniz-Visitation, 1719. 
mjesta i stereotipa, na kojima se često temelje stavovi i postupci prema drugima. ${ }^{4}$ Upravo je tu s obzirom na njihovu intenciju moguće napraviti razliku između slike koju pružaju književna djela i one povijesnih izvora, iako je i to potrebno uzeti s određenim oprezom. Povijesni izvori koji se analiziraju u tekstu rezultat su određenoga iskustva i uvida u konkretnu situaciju dvojice časnika. Pritom je važno voditi računa o okolnostima nastanka i svrsi spisa u kojemu se govori o osobinama nekoga naroda.

Slijedeći mišljenje Joepa Leerssena, koji naglašava da imagologija pojam egzistencije zamjenjuje pojmom percepcije odnosno reprezentacije, opis krajišnika i stavove o njima u spisima dvojice habsburških časnika valja shvatiti kao predodžbe i slike koje su drugi o njima posredovali, a ne kao izraz njihove biti, empirijske datosti. Pojam identiteta Leerssen ne shvaća kao jedinstvenu kategoriju nego govori o njegovu razdvajanju na identitet i alteritet, odnosno, o razlici između Sebe i Drugoga. Kada je riječ o nacionalnom ili etničkom identitetu sa stajališta imagologije, identitet se ne pokušava definirati kakav jest, već kako ga se shvaća odnosno percipira. ${ }^{5}$ Imagologija se prvenstveno bavi nacionalnim ili kulturnim stereotipima, a ne identitetima, usredotočena je na razumijevanje teksta, diskursa, a ne na društvo ${ }^{6} \mathrm{O}$ spomenutim ograničenjima imagološkog pristupa u historiografskim radovima govori i njemački povjesničar W. Höpken. On upućuje na poteškoće povjesničara prilikom istraživanja stereotipa. Historiografski je to, tvrdi Höpken, zahtjevan zadatak, jer se javlja problem relevantnih izvora. Iako ti izvori sadrže primjere stereotipa i stereotipne opise, ipak je na temelju njih teško pratiti i argumentirano istražiti učinke pojedinih stavova i stereotipa. ${ }^{7}$

Međutim, istraživanje stereotipa i slike o Drugome može se iz perspektive historije usmjeriti na niz drugih pitanja važnih za razumijevanje njihova oblikovanja. Primjerice, na pitanje o sloju nositelja i njegovom društvenom interesu i moći, zatim na društvenopovijesni okvir odnosno uvjete koji u određenom trenutku dovode do aktiviranja stereotipa kao i na mogućnosti opisa historijsko-semantičke strukture slike stranaca (njem. Fremdbilder). ${ }^{8}$

$\mathrm{Na}$ temelju spomenutih izvora može se stavove i ocjene o vojnokrajiškom sustavu i stanovništvu koje iznose Rabatta i Hildburghausen razmatrati s nekoliko aspekata - što obojica smatraju svrhom vlastitoga djelovanja u Vojnoj krajini, kako opisuju potrebe Monarhije i namjere vladara, zatim kako karakteriziraju stanovništvo i na temelju kojih osobina. Na temelju izvora analizirat će se koliko su slike i predodžbe krajišnika uvjetovane prosvjetiteljskim nazorima te koja se jezična sredstava odnosno pojmovi upotrebljavaju za karakterizaciju stanovništva Vojne krajine.

\section{Povijesni kontekst Rabattina i Hildburghausenova djelovanja}

Nastojanja oko „modernizacije“ i uvođenja reformi na brojnim područjima obilježili su Habsburšku Monarhiju u 18. stoljeću što se odrazilo i na odnos prema Vojnoj krajini i

\footnotetext{
Usp. Joep LEERSSEN, „Imagologija: povijest i metoda“, Kako vidimo strane zemlje. Uvod u imagologiju, (ur. Davor Dukić, Zrinka Blažević, Lahorka Plejić Poje i Ivana Brković), Zagreb 2009, 169-185, 178.

5 Joep LEERSSEN, „Odjeci i slike: refleksije o stranom prostoru“, Kako vidimo strane zemlje. Uvod u imagologiju, (ur. Davor Dukić, Zrinka Blažević, Lahorka Plejić Poje i Ivana Brković), Zagreb 2009, 83-124, 87.

6 ISTI, „Imagologija: povijest i metoda“, 179.

W. HÖPKEN, „Ethnische Stereotype in Südosteuropa“, 12-13.

8 Isto, 16.
} 
njezinu uređenju. Analizom narativnih izvora koje su ostavili predstavnici vojne hijerarhije pokušat će se pokazati stavove i mišljenja koje su se tijekom 18. stoljeća stvarali i prenosili unutar kruga zastupnika habsburške službene politike.

Grof Joseph Johann von Rabatta9 (1661.-1731.) dugogodišnji zapovijedajući general u Hrvatskoj vojnoj krajini (Karlovačkom generalatu) predstavnik je unutrašnjoaustrijskog plemstva podrijetlom iz Goričke grofovije i plemić s tipičnom vojnom karijerom baroknoga razdoblja. Podrijetlo i služba obvezivali su ga na umnažanje materijalnog bogatstva radi učvršćivanja statusa i uspona u društvenoj hijerarhiji kroz odanu službu vladaru. Pritom je stjecao ne samo društveni prestiž nego i znatnu materijalnu korist. Najveći dio vojne službe proveo je Rabatta na području Vojne krajine, obavljajući različite funkcije i dužnosti - od sudjelovanja u povjerenstvima za razgraničenje s Osmanskim Carstvom nakon sklapanja mira 1699. preko različitih vojnih pohoda do obnašanja funkcije zamjenika glavnog zapovjednika te glavnog zapovjednika Karlovačkoga generalata. Kao zapovjednik ostavio je početkom 18. stoljeća brojne spise s prijedlozima za uvođenjem reda i promjena te unapređenjem vojnokrajiškog sustava. Njegovi izvještaji, prijedlozi i nacrti projekata, osim brojnih i detaljnih podataka o uređenju vojno-obrambenog sustava, sadrže i obavijesti o stanovništvu. Namjera Rabattinih dopisa i izvještaja nije bila ostaviti budućim naraštajima uspomenu i mišljenje o krajiškom narodu već je opis naroda u njegovim spisima nastao kao „nusproizvod“ obavljanja njegove dužnosti i pokušaja unapređenja sustava.

Vojvoda Joseph Maria Friedrich Wilhelm Hollandinus von Sachsen-Hildburghausen (1702.-1787. ${ }^{10}$ predstavnik je visokog njemačkog plemstva iz kneževske kuće u Tiringiji. Iako se Hildburghausenov profesionalni životopis u određenoj mjeri razlikuje od Rabattina, on je također bio posvećen vojnom pozivu. Značajan trag ostavio je on u povijesti Vojne krajine osmišljavanjem preustroja vojno-organizacijskog sustava polovinom 18. stoljeća u Varaždinskom i Karlovačkom generalatu. Dokument na čiji sadržaj će se usredotočiti pozornost u ovom radu opisuje njegovo djelovanje u Hrvatskoj. Međutim, za analizu toga dokumenta važna je činjenica da je nastao više godina nakon Hildburghausenove službe u Hrvatskoj, i to kao određena vrsta retrospektivne analize vlastite uloge u hrvatskoj vojnokrajiškoj povijesti. Spis je sastavljen na poticaj i zahtjev cara Josipa II., koji je, planirajući vlastite reforme Vojne krajine, tražio detaljan uvid u prethodna stanja i poduzete mjere iz pera osobe koja je sudjelovala u kreiranju sustava. Beitrag zur Geschichte der Warasdiner und Karlstaedter Grenz Verfassung mit 112 Beylagen nije dokument koji je nastao tijekom Hildburghausenove službe u Vojnoj krajini, već predstavlja „sekundarni“ izvor u kojemu sudionik događaja opisuje vojnokrajiške prilike iz prethodnog razdoblja prema vlastitom sjećanju i na temelju izvornih dokumenata. Njegov opis je intencionalan i usmjeren na prikazivanje i „opravdanje“ vlastita djelovanja. Svoje postupke i djelovanje Hildburghausen je nastojao prikazati kroz prizmu prevladavajućeg prosvjetiteljskog svjetonazora, čijim je zagovarateljem i nositeljem bio i car Josip II., naručitelj Priloga povijesti.

Prikaz života i djelovanja Josepha Rabatte u Hrvatskoj te uloge obitelji Rabatta u habsburškoj službi pogledati u: Sanja LAZANIN, Slika Drugoga i pismo o Sebi. Josip Rabatta (1661. - 1731.) o Hrvatskoj i sebi. Zagreb 2002, (Magistarski rad).

10 O životu vojvode von Sachsen-Hildburghausena i njegovu djelovanju u Vojnoj krajini u Hrvatskoj opširnije u: Sanja LAZANIN, „Hrvatska povijest i narod u izvještaju Josepha Friedricha von Sachsen-Hildburghausena“, Godišnjak njemačke zajednice - DG Jahrbuch, Zbornik radova 17. Znanstvenog skupa "Nijemci i Austrijanci u Hrvatskom kulturnom krugu“, Osijek 2010, 55-64. 
Za daljnju analizu važno je razmotriti imaju li različiti društveno-povijesni okviri unutar kojih Rabatta i Hildburghausen djeluju utjecaj na izgradnju stavova i oblikovanje predodžbi o narodu na području Vojne krajine u konkretnoj situaciji? Razlikuju li se i u čemu slike društva koje oni konstruiraju?

Grof Rabatta i vojvoda Hildburghausen u prvom se redu bave problemima vojne službe i njezine učinkovite organizacije, dok se o gospodarskim pitanjima u njihovim opisima ne govori. Iako obojica na određeni način sudjeluju u životu krajiškoga društva njihovo djelovanje kao i pisana svjedočanstva pokazuju određene razlike u percipiranju prostora i ljudi.

Rabatti i Hildburghausenu zajedničko je to da su bili pripadnici visokog plemstva, izgrađivali su veze unutar istoga društvenoga sloja, nastojeći pritom ostvariti vlastite interese. Hildburghausen je uživao povjerenje habsburške vladajuće kuće. To se ogledalo u povjerenim službama i ovlastima u svrhu uređenja krajiškog sustava radi njegove funkcionalnosti za monarhijske potrebe. U Prilogu on opisuje kako je pristupio povjerenom zadatku i kako je vidio svrhu toga preuređenja. Navodi da je prvotna svrha granice bila „obrana protiv Turaka, odnosno protiv upada koje su isti poduzimali u 16. i 17. stoljeću“. U nastavku pojašnjenja navodi Hildburghausen da su radi zaštite unutrašnjih pokrajina (misli na Unutrašnjoaustrijske zemlje) „rubni opustošeni krajevi Hrvatske ustupljeni ratničkoj i pljačkaškoj naciji“ uz uvjet da ih štiti od Turaka. U tom dijelu Hrvatske uvedeno je vojničko uređenje, a za njegovo uzdržavanje odobrili su Unutrašnjoaustrijski staleži radi vlastite sigurnosti određeni novčani iznos kao pomoć. ${ }^{11}$ Hildburghausenova rečenica iz uvodnog dijela Priloga u kojoj objašnjava svoja nastojanja i svrhu svoga rada u Varaždinskom generalatu tridesetih godina 18. stoljeća, navodi da se od njega očekivalo da, osim smirivanja situacije koja je bila na rubu pobune uz prijeteći rat s Osmanlijama, „iznese prijedloge za bolje i korisnije uređenje sirove hrvatske nacije “. ${ }^{12}$ Njegova „retorika“ jest u skladu s prosvjetiteljskim shvaćanjima o važnosti odgoja i, što ilustrira i njegov opis vlastite uloge i svrhe uređenja oba generalata. Hildburghausen, naime, kaže da se pritom vodio mišlju na koji bi način taj dio zemlje najbolje mogao pridonijeti općem dobru, navodeći kontribuciju i osobnu vojnu službu kao mogući doprinos.

Cijeli je vojnokrajiški sustav prema Hildburghausenovu shvaćanju imao dvostruku svrhu, $s$ jedne strane uspostaviti predziđe na granici prema osmanskom teritoriju, a s druge strane te „čuvare domovine“ držati u poslušnosti. ${ }^{13}$ Hildburghausenova opservacija o potrebi uvođenja promjena sadrži i sudove koji govore o zastarjelosti sustava koji više nije primjeren „duhu vremena“ 18 . stoljeća. ${ }^{14} \mathrm{U}$ tom kontekstu Hildburghausen naglašava dvije pojave koje prema njemu bitno obilježavaju 18. stoljeće, to su: brojna i uvježbana vojska kakvu je utemeljila Pruska, pružajući na taj način izazov cijeloj Europi, i nastojanje „prosvijećene državne mudrosti" da na vojno jačanje i pripremanje za rat odgovori uspostavljanjem ravnoteže pomoću ugovora i saveza. ${ }^{15}$ Otkrivajući utjecaj prosvjetiteljskog shvaćanja o prirodnom i državnom pravu Hildburghausen u svojim promišljanjima daje prednost mudrom vođenju državne diplomacije pred ratom u rješavanju sporova između sukobljenih interesa pojedinih država, pritom ne podcjenjujući važnost i moć oružane sile i ratničke vještine.

\footnotetext{
KA, HKR-KZLA VII 349, fasc. 1, fol. 21v-22.

Isto, fol. 2.

Isto, fol. $22 \mathrm{v}$.

Isto, fol. 23.

Isto, fol. $23 \mathrm{v}$.
} 
Rabatta kao vojni zapovjednik dijela Vojne krajine imao je drukčije preferencije. Djelovao je u razdoblju novog uspostavljanja snaga i granica s Osmanlijama i Mlečanima na prijelazu 17. u 18. stoljeće, pa je i ta situacija uvjetovala njegove postupke i prioritete. ${ }^{16}$ Osim toga, kao pripadnik plemstva baroknog razdoblja obavljao je javne funkcije koje su bile u skladu s njegovim grofovskim rangom. ${ }^{17}$ Kao istaknuti vojskovođa i zapovjednik Rabatta je za odanu službu vladaru mogao računati i na znatne materijalne probitke koji su se također ostvarivali različitim putovima, vezama i snalaženjem uz vladarsko pokroviteljstvo.

\section{Rabattine i Hildburghausenove predodžbe o krajiškom stanovništvu}

Predodžbe o stanovništvu koje u svojim spisima iznose Rabatta i Hildburghausen odnose se na određene osobine ljudi u prostoru u kojemu se oni nalaze na poziciji vlasti. Te predodžbe su izrazi određenih pojednostavljenja, poopćenih mišljenja, koje im je poslužilo kao polazište i opravdanje za donošenje odluka. Obojica donose sudove o karakteru stanovništva. Pred historiografsku analizu postavlja se problem u kojoj mjeri ti sudovi koji se ponavljaju unutar habsburške zapovjedne strukture tijekom dugoga razdoblja imaju elemente stereotipa ${ }^{18}$, a koliko su ti opisi karaktera krajiškog stanovništva utemeljeni na Rabattinu i Hildburghausenovu iskustvu stečenom djelovanjem među krajišnicima?

Zajedničko obojici u njihovim opisima jesu kvalifikacije stanovništva odnosno opisivanje njegova „nacionalnog karaktera“. Zastupljenost određenih osobina u njihovim opisima poput hrabrosti, (ne)pouzdanosti, (ratničke) sposobnosti, (ne)kultiviranosti, govori ponajviše o interesima autora i njihovu kutu gledanja na ljude i zemlju u kojoj obavljaju službu.

Vojvoda Hildburghausen, koji s određenim vremenskim odmakom izvještava o svojem radu u Vojnoj krajini naglašava da mu je namjera iznijeti „povijest mnogoljudnog i ratničkog naroda koji je dugo bio zapostavljen“, ali naglašava da želi upoznati i njegov „nacionalni duh" (National-Geist) ${ }^{19}$, ono što su njemački prosvjetiteljski mislioci poput Johanna Gottfrieda Herdera nazivali Volksgeist. Već ta prva rečenica sadrži opis „karaktera naroda“, ali i daje naznake određene Hildburghausenove naklonosti gotovo pokroviteljskog stava prema tom narodu.

Taj stav, u kojemu se mogu nazrijeti utjecaji prosvjetiteljskog okruženja, vlastite pozicije i političkih prilika u vremenu nastanka spisa, razlikuje Hildburghausena ${ }^{20}$ od Rabatte.

$\overline{16}$ Rabatta u jednom od prvih izvještaja nakon preuzimanja glavnog zapovjedništva Karlovačkog generalata iz 1709. smatra da se zbog brojnih nepravilnosti koje postoje u njemu kao i zbog neprijateljstava koja prijete od strane Osmanlija i Mlečana situacija u tim krajiškim krajevima mora promijeniti radi zajedničke sigurnosti. Rabatta, iznoseći po pojedinim stavkama mišljenje o situaciji, nagoviješta svoj stav u vezi nužnih promjena. KA, HKR 219, 1709, fol. $53,54 \mathrm{v}$.

17 O društvenom statusu i službama koje su bile namijenjene grofovima u Carstvu opširnije u: Rudolf ENDRES, Adel in der Frühen Neuzeit, München 1993, 8-9.

18 Klaus Roth kaže da stereotipe možemo shvatiti kao kognitivne tvorbe koje su historijski promjenjive, ali su „ipak prilično stabilne svakodnevne kategorizacije, tipizacije okruženja“. Klaus ROT, Slike u glavama: ogledi o narodnoj kulturi u jugoistočnoj Evropi, Beograd 2000, 260.

19 KA, HKR-KZLA VII 349, fasc. 1, fol. 1v, 2.

20 Stanovništvo hrvatskog vojnokrajiškog prostora Hildburghausen opisuje kao nekultiviran i na ratove i nemire navikao narod, koji je zapomagao zbog potlačivanja i nepoštivanja svojih privilegija. KA, HKR-KZLA VII 349, fasc. 1, fol. 2 . 
Naime, u Rabattinim se izvještajima ne nalaze tvrdnje koje bi upućivale na to da je krajišnicima učinjena nekakva nepravda ili narušene privilegije, upravo suprotno, za njega su oni buntovnici, „ein, zur Empörung so geneigtes Volck“, ${ }^{21}$ koje je potrebno disciplinirati.

Ni Rabatta ni Hildburghausen u svojim opisima krajiškog stanovništva ne rukovode se isključivo etničkim kriterijem. Stanovništvu pripisuju odeđene „kolektivne identitete“ koji se temelje na vjerskoj, društvenoj, statusnoj, etničkoj, kulturnoj ili nekoj drugoj pripadnosti. Iako je obojici zajedničko da na to stanovništvo gledaju prije svega sa stajališta njegove funkcionalnosti za državu, dakle, kao na krajišnike, graničare (Grenzvolk), ipak se razlikuju u distinkciji pojedinih skupina unutar toga korpusa.

Narod koji je opisao u svojem Prilogu Hildburghausen naziva „divljim i sirovim Hrvatima “22, zatim „srčanim ljudima koji su očvrsnuli za potrebe ratovanja s Turcima“23 i naglašava „prepoznatljive izvrsne crte vojničkog duha ove nacije“. ${ }^{24}$ Hildburghausenov opis krajišnika podsjeća na „plemenitoga divljaka“ Jeana Jacquesa Rousseaua. Naziva ih „ratničkim, hrabrim narodom, sirovim jednostavnim (nepatvorenim) sinovima prirode, koji uz jednostavnu ishranu, radom i vojnom obvezom izrastaju u istinske stasite predstavnike muškog roda, žilave i čvrste kao hrastovi u šumi bez njege i kulture; dobronamjerne i divlje, a pritom praznovjerne i pune oduševljenja za vojnu čast, naviknute na opasnosti bitaka i željne pljačke“. 25

Odanost vladaru i domovini te privrženost starim narodnim običajima i navikama osobine su koje Hildburghausen posebno apostrofira kod hrvatskih krajišnika. ${ }^{26}$ Ističući njihovu svojeglavost i nepovjerenje prema nadređenima - pritom Hildburghausenova atribucija krajišnika nema ni etničko ni konfesionalno značenje, već ih naziva hrvatskima prema hrvatskom prostoru na kojemu se nalaze - Hildburghausen naglašava da su oni unatoč podčinjavanju i uskraćivanju prava i obećanih povlastica spremni iskazati odanu vjernosti i predanost carskoj službi. ${ }^{27}$

Nabrajajući osobine krajišnika odnosno njihove prirodne vrline ističe Hildburghausen važnost uloge mudroga i prosvijećenog vladara koji će taj ljudski potencijal znati upotrijebiti za ostvarivanje dobrobiti države. Hildburghausen $s$ oduševljenjem govori o smionosti Hrvata, jer su pobunama naveli svoje vladare da im posvete veću pozornost i da ih upoznaju. Hildburghausenov prosvjetiteljsko-romantičarski stav o krajišnicima i njegova ocjena „hrvatskih vojnika“ jezgrovito je izražena u rečenici: „Hrvati sa svim svojim manama i u sutonu barbarstva još uvijek su mi se činili jedinim istinskim materijalom za ideal vojnikā, kako ih je opisao Ossian. ${ }^{228}$

Hildburghausenovi opisi „plemenitog divljaka“ upućuju s jedne strane na romantičarsko gledanje na krajišnike, a s druge strane na prosvjetiteljsku namjeru „civiliziranja“ ${ }^{29}$ Navode-

\footnotetext{
KA, HKR, 1721 I 457, fol. 7v.

KA, HKR-KZLA VII 349, fasc. 1, fol. 26.

Isto, fol. $6 \mathrm{v}$.

Isto, fol. 11.

Isto, fol. $15 \mathrm{v}$.

26 U izvoru stoji: „... unerschütterliche Anhänger der alten National-Sitten und Gebräuche, und durch selbige unauflöslich an ihr Vaterland geknüpfft", KA, HKR-KZLA VII 349, fasc. 1, fol. 15v.

27 KA, HKR-KZLA VII 349, fasc. 1, fol. 15v.

28 Isto, fol. 16.

29 O prosvjetiteljskoj predodžbi o „dobrom divljaku“ opširnije u: Cvetan TODOROV, Mi i drugi, Beograd 2004, 262272.
} 
ći prirodne osobine krajišnika kao izvrsnu predispoziciju za dobre vojnike, dakle za ono za što ih Monarhija i treba, svoju kritiku usmjerava Hildburghausen na prijašnju zapovjednu strukturu, koja se loše odnosila prema krajišnicima, i na loše uređenje vojnokrajiškog sustava. Time on pred carem Josipom II. želi istaknuti vlastitu ulogu u prepoznavanju njihovih osobina korisnih za državne interese. Prema njegovu shvaćanju bilo je važno da se krajišnike prepozna kao „prirodni, sirovi materijal“ koji će pomoću mudrih i civilizirajućih mjera te dobro vođenom upravom pridonijeti općoj dobrobiti države. Ratna vještina je, sukladno Hildburghausenovu stavu, bila najkorisnije što su oni mogli ponuditi i što je Monarhiji bilo najpotrebnije u razdoblju brojnih sukoba s europskim i osmanskim protivnicima oko učvršćivanja položaja imperijalne sile.

U karakterizaciji krajišnika Karlovačkoga generalata upotrebljava grof Rabatta slične izraze kao i Hildburghausen, međutim, povjesničar prilikom njihove analize mora uzeti u obzir kontekst nastanka i njihov semantički potencijal. On ih naziva „neukrotivim narodom" (dieses vnbändige Volckh) koji bi valjalo bolje obuzdati kako bi se spriječile sve učestalije pljačke, razbojstva i ubojstva. ${ }^{30}$ Pritom naglašava da je Vlahe, koje također naziva neukrotivima, potrebno „civilizirati“ uz pomoć njemačkih jedinica. ${ }^{31} \mathrm{U}$ toj Rabattinoj preporuci i stavu o Vlasima, može se uočiti nekoliko opreka. S jedne strane, „civilizaciju“ (njemačku) suprotstavlja „barbarstvu“ (vlaškom), zatim zamišljene „Mi“ (Rabatta i njemačke jedinice) stavlja u opreku s „Drugima“ (krajišnicima), koje je potrebno „privesti nama“, drugim riječima, učiniti ih korisnima za potrebe krajiške obrane odnosno habsburških posjeda.

U izvještaju iz 1729. Rabatta govori o propuštenoj prilici tijekom zadnjega rata s Osmanlijama da se osvoji Bihać i da ga se uključi u sastav Hrvatske krajine. Kao razlog neuspjeha navodi nesređenost granice i loše stanje krajiške vojske, koja prema njegovu mišljenju više nalikuje na „tatarsku hordu“ nego na vojsku, iako ih predvode čestiti i u ratu prokušani časnici. ${ }^{32}$ Situacija u kojoj Rabatta djeluje i govori o krajišnicima jest nesređeno stanje nakon određivanja granica krajiškog prema osmanskom teritoriju i migracija brojnoga stanovništva nakon ratova s Osmanlijama (Bečkog rata 1683.-1699. i Prvoga turskog rata 1716.-1718.). Upravni i vojni aparat nisu bili dobro organizirani, jer nisu postojala sustavna rješenja od strane države. Štoviše, ni središnja uprava nije bila jedinstvena. U to su vrijeme unutrašnjoaustrijski staleži imali još uvijek veliku ulogu u upravljanju Karlovačkim i Varaždinskim generalatom i presudnu riječ prilikom postavljanja zapovjednika. Tek od sredine 18. stoljeća i nakon Hildburghausenovih reformi taj će sustav poprimiti sve više oblik centraliziranoga i uređenoga vojnog aparata na čelu s Ratnim vijećem i vladarom. Taj je proces našao i svoj pravni ishod u dokumentu Militar-Granitz-Rechten, donesenom sredinom 18. stoljeća.

Rabattin i Hildburghausenov stav o krajiškom stanovništvu razlikuju se u tome što Rabattini izvještaji i opisi odražavaju trenutačnu situaciju u Vojnoj krajini početkom 18. stoljeća, dok je Hildburghausenovo mišljenje utemeljeno u povijesnoj situaciji. On opisuje krajišnike uzimajući u obzir njihov povijesni razvitak i prilagođavajući predodžbe i stavove o njima svojim shvaćanjima ljudske prirode. Hildburghausen izdvaja tri pojma koji bitno određuju postupke ljudi; to su religija, sloboda i interes. ${ }^{33}$ Temeljeći svoje djelovanje na tim

\footnotetext{
30 Hrvatski državni arhiv, Zagreb (dalje: HDA), Karlovački generalat (dalje: KG), Uvezani spisi, knj. 1, br. 56, fol. 94v. 1 HDA, KG, Uvezani spisi, knj. 1, br. 55, fol. 76v.

Isto, br. 67, fol. 161.

33 U izvoru stoji „... Religion, Freyheit, und Interesse, diese drey große Triebfedern des menschlichen Geschlechts, waren zu diesem Endzweck benutzt worden.“ KA, HKR-KZLA VII 349, fasc. 1, fol. 19v.
} 
postulatima nastojao je Hildburghausen pridobiti krajišnike za svoje planove i prilagoditi sustav potrebama državne uprave utemeljene u prosvjetiteljskim reformama.

Obojica časnika u svojim opisima primjenjuju etničku karakterizaciju u smislu da iznose svoje predodžbe i stavove o nekom drugom narodu - heteropredodžbu. Iako ni „promatrano" ni „promatrač " nisu u analiziranim izvorima prvenstveno kategorizirani nacionalnim terminima, uočava se razlika između oba autora u navođenju etničke pripadnosti krajišnika. Rabatta, za razliku od Hildburghausena, naglašava razliku u stavu prema katoličkom i pravoslavnom stanovništvu, odnosno Hrvatima i Vlasima kako ih naziva u svojim izvještajima. ${ }^{34}$ Radi sigurnosti granice i lakšeg organiziranja vojne službe Rabatta naglašava da je potrebno razdvojiti Vlahe od Hrvata i dodijeliti im posebna zemljišta. ${ }^{35}$ Nepovjerenje je Rabatta iskazivao prema novodoseljenim Vlasima, jer ih je sumnjičio da održavaju veze s osmanskom stranom. Zalagao se za to da ih se naseli dalje od granične crte prema osmanskom teritoriju, a umjesto njih da se naseli „katolike i $\mathrm{Hr}$ vate“ ${ }^{36} \mathrm{Za}$ pravoslavno stanovništvo Karlovačkog generalata upotrebljava Rabatta izraz „Schismaticis“. Smatrao je da ih je potrebno postupno privoditi crkvenoj uniji u skladu s dvorskom politikom kao i s njegovim katoličkim opredjeljenjem. Osim toga prema pravoslavnim stanovnicima Generalata izražava nepovjerenje i opisuje ih kao prevrtljive i nepouzdane, tvrdeći da su, kad njima to odgovara, dobri i slijede zapovjedi nadređenih, međutim, kad izgube volju tada kod njih nestaje svakog poštovanja i poslušnosti. ${ }^{37}$

Rabattini opisi pojedinih lokalnih zajednica govore o samom načinu funkcioniranja sustava, koji u to vrijeme nije bio jedinstveno organiziran, ali i o njegovoj upućenosti u stanje u pojedinim krajiškim zajednicama. Kod Hildburghausena nema takve distinkcije. Uspoređujući Rabattine stavove i opise lokalno diferenciranih krajiških zajednica može se uočiti njegov negativan stav prema Senjanima. Rabatta navodi da je „oholost Senjana nepodnošljiva" $i \mathrm{da}$ im je vojna stega omražena te da nastoje izbjeći vojne obveze. On im doduše priznaje da su „dobri i srčani ljudi“ te kaže da ih je najbolje upotrijebiti za različite službe na moru. ${ }^{38}$ Loše mišljenje iznosi Rabatta i o cijeloj Primorskoj krajini. U njegovoj ocjeni toga dijela krajiškog prostora naglašava se znatno lošije vojnoorganizacijsko stanje u usporedbi s Hrvatskom krajinom. Posebno ističe nepovjerenje koje on, kao zapovjednik Generalata, ima prema krajišnicima, kako običnim vojnicima tako i domaćim časnicima (National-Officiers). Rabatta svoju ocjenu primorskih krajišnika zaključuje stavom da su svi primorski krajišnici istoga kova, drugim riječima, nepopravljivi. ${ }^{39}$

U Hildburghausenovim opisima naglašen je interes za vojnu dimenziju Hrvata, pri čemu njega ne zanima hrvatska državno-pravna tradicija, on ne spominje staleže, niti govori o hrvatskom stanovništvu izvan Vojne krajine. Uvodni dio u kojemu opisuje povijest prostora i hrvatskog naroda služi mu samo kako bi pokazao njihove predispozicije za ratne vještine i da na temelju povijesnog iskustva izabere najprikladniji način za provođenje svojih reform-

Ti stavovi odnosno stereotipi ne mogu se poistovjetiti sa etničkim stereotipima koji nastaju u 19. stoljeća u kontekstu izgradnje nacija. Höpken naglašava da su etnički stereotipi nešto drugo od srednjovjekovnih toposa razgraničenja ili stereotipa koji su nastali iz konfesionalnih suprotnosti i ratnih iskustava u epohi turskih ratova. W. HÖPKEN, "Ethnische Stereotype in Südosteuropa", 18.

35 HDA, KG, Uvezani spisi, knj. 1, br. 53, fol. 51.

36 Isto, br. 55, fol.75.

37 KA, HKR, 1721 I 457, Expedit, fol. 9.

38 KA, HKR, 1721 I 457, Expedit, fol. 27-27v.

39 Isto, fol. $28 \mathrm{v}$. 
skih mjera. ${ }^{40}$ Njegova nastojanja da upozna i opiše narod u Vojnoj krajini odražavaju instrumentalni pristup prema krajišnicima. Prosvjetiteljske namjere vladara i drugih promicatelja tih ideja u okviru države dobrobiti i blagostanja usmjerene su na poučavanje i preodgoj stanovništva radi učinkovitijeg usmjeravanja njihovih potencijala za opću državnu korist.

U Rabattinim i Hildburghausenovim konceptima krajiške zajednice se javljaju kao segmentirane tradicionalne zajednice. Njihov stav i predodžbe o krajišnicima proizlaze, $s$ jedne strane, iz monarhijske politike, ovisno što je bilo u fokusu zanimanja državne politike $\mathrm{u}$ određenom razdoblju, primjerice, vojne osobine stanovnika, njihova brojnost, način života i privređivanja odnosno njihova konfesionalna pripadnost i slično. $S$ druge strane, Rabattina distinkcija pojedinih skupina stanovništva slojevitija je i raznovrsnija nego što je to slučaj kod Hildburghausena. To ujedno može biti i odraz duljeg boravka među krajišnicima kao i boljeg poznavanja situacije, međutim, to još uvijek ne znači da je Rabattin stav empirijski utemeljeniji ${ }^{41}$ i time manje podložan stereotipizaciji nego Hildburghausenov.

Pojmovi koje u opisu vojnokrajiške situacije upotrebljavaju Rabatta i Hildburghausen govore o vremenu u kojem su izvještaji nastali, o prevladavajućim interesima državne nomenklature te kulturnom i svjetonazorskom okruženju. Međutim, kao što ističe Reinhart Koselleck, semantički potencijal pojedinih pojmova i njihova jezična uporaba ne određuju se prema govornicima koji ih upotrebljavaju. Drugim riječima, povijest jezika može se odvojiti od povijesti govornika, odnosno uporaba jezika i promjena značenja pojedinih pojmova ne ovise o interesima i namjerama govornika. ${ }^{42} \mathrm{Na}$ temelju relativno maloga broja analiziranih spisa u ovom radu mogu se uočiti određeni pojmovi koje Rabatta i Hildburghausen često upotrebljavaju, a koji u razdoblju prosvjetiteljstva postaju frekventni i semantički se redefiniraju. U Hildburghausenovu opisu to su pridjev „National“ i imenica "Nation“. 43 Oba pojma upotrebljava i Rabatta u svojim izvještajima. ${ }^{44}$ Pojam narod $(\text { Volk })^{45}$, domovina $(\mathrm{Va}$ terland $)^{46}$, država (Staat), opće dobro (allgemeines Wohl $)^{47}$, civilizirati ${ }^{48}$, često se spominju u njihovim opisima vojnokrajiških prilika. Ti izrazi koji su u jezičnom smislu stari dobivaju tijekom 18. stoljeća kao pojmovi nova značenja i veliku propulzivnost.

$40 \ldots$ weil Ich blos darinnen die schicklichsten Mittel zu Erfüllung Meines Auftrags finden konnte: Auch gab Ich Mir alle Mühe Mir diese Kenntniße zu verschaffen“KA, HKR-KZLA VII 349, fasc. 1, fol. 2.

41 O predodžbama i slikama o Drugome te njihovoj utemeljenosti na konkretnom iskustvu ističe Klaus Roth sljedeće: „Predstave o strancima i istorijske predstave su, dakle, slike u glavama koje smo tek veoma retko svesno izgradili po sopstvenom iskustvu, već smo ih po pravilu bez daljeg osporavanja usvojili kao deca, procesom socijalizacije i akulturacije ...", K. ROT, Slike u glavama, 267.

42 Reinhart KOSELLECK, Begriffsgeschichten: Studien zur Semantik und Pragmatik der politischen und sozialen Sprache, Frankfurt am Main 2006, 314-315.

43 Ti pojmovi se upotrebljavaju u sljedećim sintagmama: National-Miliz, National-Charakter, Griechischen Bischoffs und anderer Nationalen, der rohen Croatischen Nation, National-Sitten und Gebräuche, National-Geist.

44 National-Volck, National-Officier, dise nation von denen üblesten, vnd inraisonablesten leuthen, diese Nation aber ist zu wasser mit mehrern Vortl zu gebrauchen als zu land, eine nation so trans-Kolapiani genent werden.

45 Primjeri konteksta u kojemu je riječ upotrijebljena: das Volck lag in einem gesetzlosen verwilderten Zustande; das Gränzvolck zu Fuß und Pferd kod Hildburghausena, mit so muthwilligem volck besezten Posten kod Rabatte.

46 U izvorima stoji: durch die sanften Lehren des Christenthums zu beßeren Sitten und Vaterlandsliebe gebildet, unauflöslich an ihr Vaterland geknüpfft.

47 Hildburghausen govori o općem dobru i dobrobiti države: zu dem allgemeinen Wohl, dem Wohl des Staate.

48 Kod Rabatte se u tekstu nalazi i neologizam: die unbändigen Wallachen vermittels Teütscher association civilisiret. 


\section{Zaključak}

Analiza opisa krajiškog stanovništva, koje su u službenim spisima ostavili grof Rabatta i vojvoda Hildburghausen, upućuje na zaključak da su oni svojim djelovanjem, ali i pisanjem, na određeni način konstruirali krajiško društvo. Na temelju analiziranih izvora pokušalo se utvrditi razlike u oblikovanju stavova i predodžbi dvojice habsburških časnika u 18. stoljeću o hrvatskoj Vojnoj krajini, posebice o njezinu stanovništvu - pravoslavnom i katoličkom. Ono što prelazi okvire ovoga rada jest pitanje, u kojoj su mjeri izrečeni stavovi obojice časnika preuzeti od njihovih prethodnika kao dio „stereotipnog mišljenja“, a u kojoj su mjeri ti stavovi doneseni na temelju vlastitih uvida.

Rabatta i Hildburghausen međusobno se razlikuju po tome što Rabattini izvještaji i opisi bilježe trenutačnu situaciju u Vojnoj krajini početkom 18. stoljeća, dok se Hildburghausen u pisanju svog izvještaja oslanja na širu povijesnu perspektivu. Rabattin stav je kritički i negativno intoniran, izražava veliko nepovjerenje osobito prema pravoslavnim Vlasima. Opravdavajući svoje postupke i neuspjehe pri pokušajima uvođenja bolje organizacije u pogranična područja Rabatta traži izliku u lošim osobinama krajišnika. Hildburghausen, međutim, navodeći negativne osobine i uočavajući naznake barbarstva kod krajišnika čini to s određenom naklonošću prema njima kao prema plemenitim divljacima. Za njega su krajišnici u Hrvatskoj dobar potencijal koji, uz pomoć dobre uprave i voljom prosvjetiteljski nastrojenih vladara, može poslužiti dobrobiti cijele države. Uzroke različitih problema u Vojnoj krajini Hildburghausen ne nalazi u samom narodu nego kritiku usmjerava na lošu upravu i zapovjednike. Time on daje legitimnost svojem radu na preustroju oba generalata i poticaj daljnjim reformama Vojne krajine u skladu sa zahtjevima novoga vremena i novih političkih konstelacija.

Rabatta i Hildburghausen stvaraju predodžbe o stanovništvu ističući određene osobine ljudi u prostoru u kojemu se nalaze kao predstavnici vlasti. Osobine krajišnika koje obojica ističu otkrivaju političke i svjetonazorske stavove samih autora, njihovo iskustvo i svrhu njihova djelovanja. $\mathrm{Na}$ temelju stavova i predodžbi o krajišnicima oni su donosili konkretne administrativne i vojne odluke.

\section{Die Aufklärung und Vorstellungen ÜBER DiE Bevölkerung DER Militärgrenze im I8. JAHrhundert}

In diesem Aufsatz geht man von der Annahme aus, dass sich der Einfluss der in der Habsburgermonarchie in zahlreichen Lebensbereichen im 18. Jahrhundert durchgeführten Veränderungen und Reformen auch in der Perzeption und dem Bild des Anderen spiegelt. Für die Analyse wurden narrative Quellen ausgewählt, in denen die Militärgrenzgesellschaft von zwei Habsburger Offizieren, dem Grafen von Rabatta und dem Herzog von Sachsen-Hildburghausen, geschildert wurde. Die Autorin versuchte aufgrund der Komparation von Beschreibungen beider Offiziere, sowohl Vorstellungen und Meinungen über kroatische und serbische Bevölkerung in der kroatischen Militärgrenze Anfang und Ende des 18. Jahrhunderts als auch Elemente, aus welchen sie zusammengesetzt wurden, festzustellen. Die Aufmerksamkeit wird auch auf bestimmte für die 
Aufklärung charakteristische Begriffe gelenkt, die beide Habsburger Offiziere in ihren Schriften verwenden. Es wird zusammengeschlossen, dass traditionelle Militärgrenzgemeinschaften in den Schilderungen von Rabatta und Hildburghausen segmentiert auftauchen und in ihren Beschreibungen Interessen und Erwartungen der monarchischen Politik von der Militärgrenzgesellschaft widerspiegelt wurden.

Schlüsselwörter: Aufklärung, Vorstellungen und Bilder des Anderen, Militärgrenzbevölkerung, Militärgrenze

\section{$\cos$}

\section{Literatura}

Davor DUKIĆ, Zrinka BLAŽEVIĆ, Lahorka PLEJIĆ POJE i Ivana BRKOVIĆ (ur.), Kako vidimo strane zemlje. Uvod u imagologiju, Zagreb 2009.

Rudolf ENDRES, Adel in der Frühen Neuzeit, München 1993.

Helga FISCHER, "Das Osmanische Reich in Reisebeschreibungen und Berichten des 18. Jahrhunderts", Wiener Beiträge zur Geschichte der Neuzeit. Das Osmanische Reich und Europa 1683 bis 1789: Konflikt, Entspannung und Austausch, sv. 10, Wien 1983, 113-142.

Maximilian GROTHAUS, "Zum Türkenbild in der Adels- und Volkskultur der Habsburgermonarchie von 1650 bis 1800", Wiener Beiträge zur Geschichte der Neuzeit. Das Osmanische Reich und Europa 1683 bis 1789: Konflikt, Entspannung und Austausch, sv. 10, Wien 1983, 63-88.

Wolfgang HÖPKEN, „Ethnische Stereotype in Südosteuropa”, Das Bild des Anderen in Siebenbürgen. Stereotype in einer multiethnischen Region, (ur. Konrad Gündisch, Wolfgang Höpken i Michael Markel), Köln - Weimar - Wien 1998, 7-31.

Reinhart KOSELLECK, Begriffsgeschichten: Studien zur Semantik und Pragmatik der politischen und sozialen Sprache, Frankfurt am Main 2006.

Sanja LAZANIN, Slika Drugoga i pismo o Sebi. Josip Rabatta (1661. - 1731.) o Hrvatskoj i sebi. Zagreb 2002, (Magistarski rad).

Sanja LAZANIN, „Hrvatska povijest i narod u izvještaju Josepha Friedricha von Sachsen-Hildburghausena", Godišnjak njemačke zajednice - DG Jahrbuch, Zbornik radova 17. Znanstvenog skupa "Nijemci i Austrijanci u Hrvatskom kulturnom krugu", Osijek 2010, 55-64.

Joep LEERSSEN, „Odjeci i slike: refleksije o stranom prostoru“, Kako vidimo strane zemlje. Uvod u imagologiju, (ur. Davor Dukić, Zrinka Blažević, Lahorka Plejić Poje i Ivana Brković), Zagreb 2009, 83-124.

Joep LEERSSEN, „Imagologija: povijest i metoda“, Kako vidimo strane zemlje. Uvod u imagologiju, (ur. Davor Dukić, Zrinka Blažević, Lahorka Plejić Poje i Ivana Brković), Zagreb 2009, 169-185.

Dubravka ORAIĆ TOLIĆ i Ernő KULCSÁR SZABÓ (ur.), Kulturni stereotipi: koncepti identiteta u srednjoeuropskim književnostima, Zagreb 2006.

Klaus ROT, Slike u glavama: ogledi o narodnoj kulturi u jugoistočnoj Evropi, Beograd 2000.

Pierre SERNA, „Der Adlige“, Der Mensch der Aufklärung (ur. Michel Vovelle), Frankfurt am Main 1998, 42-97.

Franz K. STANZEL (ur.), Europäischer Völkerspiegel. Imagologisch-ethnologische Studien zu den Völkertafeln des frühen 18. Jahrhunderts. Heidelberg 1999.

Cvetan TODOROV, Mi i drugi, Beograd 2004.

Michel VOVELLE (ur.), Der Mensch der Aufklärung, Frankfurt am Main 1998. 